\title{
The Structural Gene for NADP L-Glutamate Dehydrogenase in Aspergillus nidulans
}

\author{
By J. R. KINGHORN AND J. A. PATEMAN \\ Department of Genetics, University of Glasgow, Glasgow GI I 5 JS
}

(Received 8 August 1974; revised 3 October 1974)

\begin{abstract}
SUMMARY
A total of 4I mutants lacking NADP L-glutamate dehydrogenase (NADP-GDH) activity have been studied. All the mutations were located at the $g d h A$ locus within $0.1 \%$ recombination of $g d h A I$. Two mutants, $g d h A I$ and $g d h A 2$, out of five examined, produced cross-reacting material which neutralized NADP-GDH antiserum. The mutant $g d h A g$ has altered $K_{m}$ values for all five substrates: ammonium, $\alpha$-ketoglutarate, L-glutamate, NADPH and NADP. The mutant gdhA2o had temperature-sensitive growth, abnormal ammonium-regulation characteristics and thermolabile NADP-GDH activity. These results show that $g d h A$ is the structural gene for NADP-GDH.
\end{abstract}

\section{INTRODUCTION}

In Aspergillus nidulans a number of otherwise unrelated enzyme and transport systems are regulated by ammonium (Pateman, Kinghorn, Dunn \& Forbes, 1973). These systems include nitrate reductase (Pateman \& Cove, 1967), xanthine dehydrogenase (Scazzocchio \& Darlington, 1968), extracellular protease (Cohen, 1972, 1973), amidases (Hynes \& Pateman, I970 a, b), L-glutamate transport (Kinghorn \& Pateman, I972; Pateman, Kinghorn \& Dunn, I974), urea transport (Dunn \& Pateman, 1972) and ammonium transport itself (Pateman, Dunn, Kinghorn \& Forbes, 1974). Kinghorn \& Pateman (1973a) described mutants gdhAr to $A 9$ which were insensitive to this control and simultaneously lacked NADP L-glutamate dehydrogenase (NADP-GDH) activity. There were two main possibilities concerning the nature of the $g d h A$ mutations. They might be in a structural gene for NADPGDH and result in altered NADP-GDH levels, bringing about the loss of ammonium control directly (Pateman et al. 1973), or indirectly by altering the level of an important metabolite. Alternatively, the mutations might be in a regulator gene, the altered product of which resulted in loss of ammonium control and simultaneous total repression of NADP-GDH. Since NADP-GDH might be a control element in ammonium regulation and mutation in at least one other gene, $a m r B r$, can result in low NADP-GDH activity (Kinghorn \& Pateman, 1973 b, and unpublished observations), it was desirable to establish if $g d h A$ was the structural gene for NADP-GDH. We have shown that mutation in the $g d h A$ locus can result in the production of altered forms of NADP-GDH and consequently that $g d h A$ is the structural gene for NADP-GDH.

\section{METHODS}

Growth of mycelium, NADP-GDH assay and genetic analysis were as described by Kinghorn \& Pateman (I973a). Ammonium regulation of nitrate reductase, xanthine dehydrogenase and urea transport was determined by plate tests (Pateman et al. 1973). 
Media and supplements. Medium used for genetic analysis was essentially that described by Pontecorvo, Roper, Hemmons, MacDonald \& Bufton (1953). Nitrogen-less minimal medium ( $-\mathrm{N}$ medium) and carbon- and nitrogen-less minimal medium $(-\mathrm{CN}$ medium) were used (Kinghorn \& Pateman, I973a).

Isolation of more gdhA mutants. $N$-methyl- $N$ '-nitro- $N$-nitrosoguanidine (NTG)-treated conidia (Adelberg, Mandel \& Chen, 1965) of bir (a biotin auxotroph; Glasgow No. 05I) were spread over $-\mathrm{N}$ medium $+10 \mathrm{~mm}$-glutamate at $37^{\circ} \mathrm{C}$. After 2 days' incubation the colonies were replicated on to $-\mathrm{N}$ medium $+100 \mathrm{~mm}$-ammonium tartrate and incubated at $37^{\circ} \mathrm{C}$. Colonies unable to grow were purified and retested on $-\mathrm{N}$ medium $+100 \mathrm{mM}$ ammonium tartrate at 25 and $37^{\circ} \mathrm{C}$.

Preparation of antibodies against NADP-GDH. A $2 \mathrm{ml}$ portion of crude extract (3 mg protein/ml) of wild-type cells, grown on $-\mathrm{N}$ medium + Io mM-ammonium tartrate in 0.05 M-sodium phosphate buffer $\mathrm{pH} \mathrm{7.5}$, was thoroughly mixed with $2 \mathrm{ml}$ complete Freund's adjuvent. This was injected intramuscularly into the large muscle of the hind leg of a New Zealand white rabbit. This procedure was repeated, with the exception that incomplete Freund's adjuvent was used, three times at weekly intervals. The rabbit was bled before the first and after the last injection. The blood was allowed to clot by keeping overnight in a refrigerator at $4{ }^{\circ} \mathrm{C}$. The serum was decanted, centrifuged and concentrated by dialysing overnight against saturated $\left(\mathrm{NH}_{4}\right)_{2} \mathrm{SO}_{4}$. The precipitate was dissolved in $0.05 \mathrm{M}$-sodium phosphate buffer $\mathrm{pH} 7.5$ and dialysed against this buffer.

Cross-reacting material (c.r.m.) tests. Antiserum (0.1 ml) was added to $0.05 \mathrm{ml}$ wild-type extract (I mg protein/ml) and incubated at $37^{\circ} \mathrm{C}$ for $20 \mathrm{~min}$. It was found that this inhibited NADP-GDH activity by 60 to $65 \%$. No inhibition was observed when extracts were incubated with non-immune serum.

The ability of extracts of mutant NADP-GDH to protect wild-type NADP-GDH against anti-NADP-GDH serum was tested as follows. Antiserum $(0 \cdot \mathrm{I} \mathrm{ml})$ was added to $0.05 \mathrm{ml}$ mutant extract (I $\mathrm{mg}$ protein $/ \mathrm{ml}$ ). This was incubated at $37^{\circ} \mathrm{C}$ for $20 \mathrm{~min}$. Then $0.05 \mathrm{ml}$ of wild-type extract (I mg protein/ml) was added and re-incubated at $37{ }^{\circ} \mathrm{C}$ for $20 \mathrm{~min}$, after which the mixture was assayed for NADP-GDH activity. The c.r.m. is expressed as a percentage of test wild-type NADP-GDH activity protected by mutant extracts.

Electrophoresis. Crude cell extracts were analysed by Smithies' (1955) starch gel technique using hydrolysed starch (Connaught Laboratories) and the discontinuous tris-buffer system of Poulik (1957). Electrophoresis was complete in about $5 \mathrm{~h}$ using a potential drop of 9 to $10 \mathrm{~V} / \mathrm{cm}$. On completion of electrophoresis the gels were sliced into three layers and the middle layer stained for NADP L-glutamate dehydrogenase. Staining for NADP-GDH activity was based on the method of Markert \& Moller (I959 modified by Fincham \& Stadler (1965).

\section{RESULTS}

\section{Isolation and genetics of mutants lacking NADP-GDH}

In addition to ten $g d h A$ mutants already known (Kinghorn \& Pateman, 1973a; Arst \& MacDonald, 1973) a further 31 mutants, gdhAII to $A 42$, were isolated on the basis of sensitivity to high concentrations of ammonium ( $-\mathrm{N}$ medium $+200 \mathrm{~mm}$-ammonium) at $25{ }^{\circ} \mathrm{C}$. They were found to have decreased NADP-GDH activities, from zero to $20 \%$ of wild type. These mutants were crossed to $g d h A I$ and all but three gave no wild-type recombinants in 5000 progeny. $g d h A I 3, g d h A 2 I$ and $g d h A 26$ showed $0.1,0.05$ and $0.05 \%$ recombination, respectively, with $g d h A T$. 
Table I. Cross-reacting material in gdhA mutants

$\begin{array}{lc}\begin{array}{c}\text { Strain under } \\ \text { test for }\end{array} & \begin{array}{c}\text { Amount of } \\ \text { c.r.m. } \\ \text { (\% wild-type } \\ \text { NADP-GDH } \\ \text { activity }\end{array} \\ \text { Wild type } & \text { protected) } \\ \text { gdhA I } & 100 \\ \text { gdhA2 } & 73 \\ \text { gdhA3 } & 68 \\ \text { gdhA4 } & 0 \\ \text { gdh } A 9 & 0 \\ \end{array}$

* A cell-free extract of each strain under test was incubated for $20 \mathrm{~min}$ at $37^{\circ} \mathrm{C}$ with anti-sera against NADP-GDH. Wild-type extract was then added and re-incubated for $20 \mathrm{~min}$ at $37^{\circ} \mathrm{C}$. After this time, NADP-GDH activity of the mixture was assayed. Mycelium was grown at $25^{\circ} \mathrm{C}$ on $-\mathrm{N}$ medium $+0.15 \%$ Casamino acids $+5 \mathrm{~mm}$-ammonium tartrate for $15 \mathrm{~h}$ before transfer to treatment media $(-\mathrm{N}$ medium + $5 \mathrm{~mm}$-ammonium tartrate) for $5 \mathrm{~h}$.

\section{Complementation tests}

We have shown that gdhAI did not complement with the mutants $g d h A 2$ to $A 9$ in the heterozygous diploids; moreover, heterokaryons made between all possible combinations of $g d h A I$ to $A g$ failed to produce complementation (Kinghorn \& Pateman, I973a). Since it was not practical to construct diploids between all combinations of $g d h A I$ to $g d h A 4 I$, complementation was tested in heterokaryons. These tests were carried out on media on which $g d h A$ mutants grow poorly compared with the wild type: $-\mathrm{N}$ medium $+200 \mathrm{~mm}-$ ammonium at $25^{\circ} \mathrm{C}$ (Kinghorn \& Pateman, I973a), and $-\mathrm{CN}$ medium $+\mathrm{I} \%$ acetate + Io mM-ammonium at $37^{\circ} \mathrm{C}$ (Arst \& MacDonald, 1973). No increased growth was observed in heterokaryons between all combinations of $g d h A I$ to $g d h A 4 I$ on either medium.

Lack of NADP-GDH activity may not be strictly correlated with high ammonium sensitivity or with growth on acetate, and this may be the reason for the lack of complementation between $g d h A$ mutants in these tests. However, it is more likely to be due to technical reasons, since complementation has been observed in the case of NADP-GDH minus mutants in the related fungus Neurospora crassa (Pateman \& Fincham, 1964; Fincham \& Stadler, 1965).

\section{Tests for cross-reacting material}

Table I shows the ability of cell-free extracts of wild-type and $g d h A I, A 2, A 3, A 4$ and $A 9$ to protect wild-type NADP-GDH against NADP-GDH antiserum. $g d h A I$, gdhAz and $g d h A 9$ gave high levels of protection, showing that their proteins reacted with the antiserum, i.e. they were c.r.m. positive. In contrast, $g d h A 3$ and $g d h A 4$ gave no protection and were therefore c.r.m. negative.

\section{Enzyme kinetics}

The results presented in Table 2 show the $K_{m}$ values for wild-type and gdhAg NADPGDH for all five substrates. The $K_{m}$ value for each substrate was determined at saturating concentrations of the non-varying substrates. The gdhAg enzyme had abnormally high constants for all substrates, especially ammonium and $\alpha$-ketoglutarate where the mutant $K_{m}$ is approximately I5 times that of the wild-type. The wild-type Aspergillus nidulans $K_{m}$ values for ammonium, $\alpha$-ketoglutarate, NADPH and NADP are similar to that of wildtype $N$. crassa NADP-GDH, while the $K_{m}$ for L-glutamate is significantly higher (Fincham \& Bond, 1960). 
Table 2. Properties of NADP-GDH activity in wild type and gdhA9

$\begin{array}{lcc}\text { Substrate } & \text { Wild type } & \text { gdhA9 } \\ \mathrm{NH}_{4}{ }^{+} & \mathrm{K} \cdot \mathrm{I}(\mathrm{mM}) & 15.3 \\ \alpha \text {-Ketoglutarate } & 3 \cdot 4 & 36.4 \\ \mathrm{NADPH}_{2} & 0.02 & 0.08 \\ \text { L-Glutamate } & 42 & 55 \\ \text { NADP } & 0.03 & 0.10\end{array}$

Each value is the average of three independent experiments. See Table $\mathrm{I}$ for growth of mycelium.

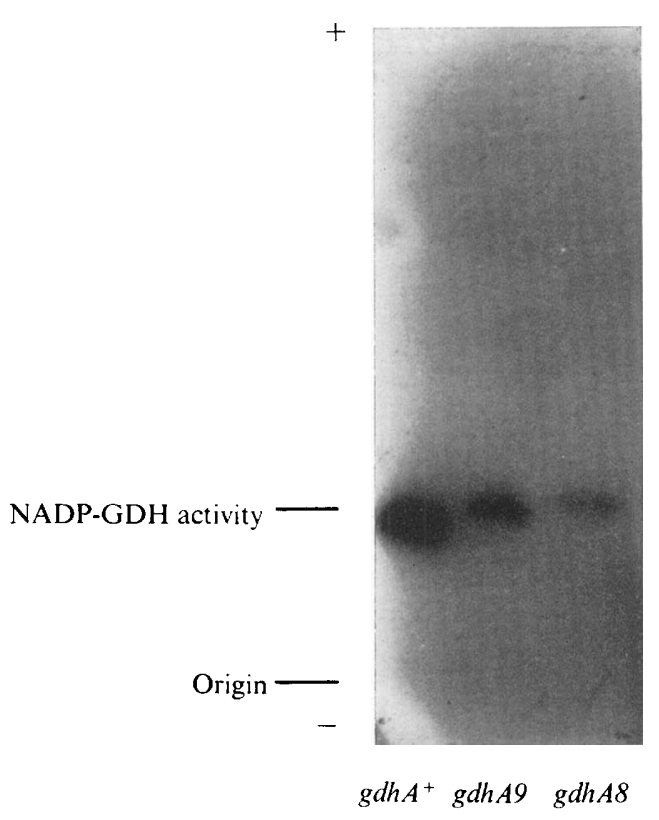

Fig. I. Starch gel electrophoresis, showing NADP-GDH activity extracts of strains of A. nidulans. For growth of mycelium, see Table I.

\section{Electrophoretic mobility of mutant NADP-GDH protein}

From Fig. I, depicting a starch gel stained specifically for NADP-GDH activity, it can be seen that there is only one band of activity in the wild-type strain, as was found in N. crassa (Fincham \& Stadler, 1965; Stachow \& Sanwal, 1967). Only the mobilities of two mutant proteins which have detectable activity are shown: $g d h A 8$, the least detectable activity, and $g d h A g$, the maximum detectable activity. A faint band was observed for $g d h A 8$ and a heavier band for $g d h A 9$. A direct comparison of activity with the wild-type, as judged by the band density, cannot be made since the concentration of mutant protein extracts was approximately four times that of the wild-type. The bands of activity in the mutants appeared at approximately the same position as in the wild-type extracts showing that enzymes produced in the mutants $g d h A g$ and $g d h A 8$ (and also the other $g d h A$ mutants which showed NADP-GDH including the temperature-sensitive $g d h A 20$ ) have similar NADP-GDH electrophoretic mobilities to the wild-type enzyme. 
Table 3. Growth responses of gdhA20 at 25 and $37^{\circ} \mathrm{C}$

\begin{tabular}{|c|c|c|c|c|}
\hline \multirow[b]{3}{*}{$\begin{array}{l}\text { Addition to } \\
-\mathrm{N} \text { medium }\end{array}$} & \multicolumn{4}{|c|}{ Genotypes } \\
\hline & \multicolumn{2}{|c|}{$g d h A I$} & \multicolumn{2}{|c|}{ gdhA2o } \\
\hline & $37^{\circ} \mathrm{C}$ & $25^{\circ} \mathrm{C}$ & $37^{\circ} \mathrm{C}$ & $25^{\circ} \mathrm{C}$ \\
\hline IOO mM-ammonium & \pm & - & \pm & ++ \\
\hline Io mM-ammonium & + & \pm & + & ++ \\
\hline Io mM-nitrate & + & \pm & + & ++ \\
\hline Io mM-urea & + & \pm & + & ++ \\
\hline
\end{tabular}

Growth on agar plates was scored as follows: ++ , strong growth (wild-type growth with each nitrogen source and at both temperatures); +, growth; \pm , poor growth; - , no growth.

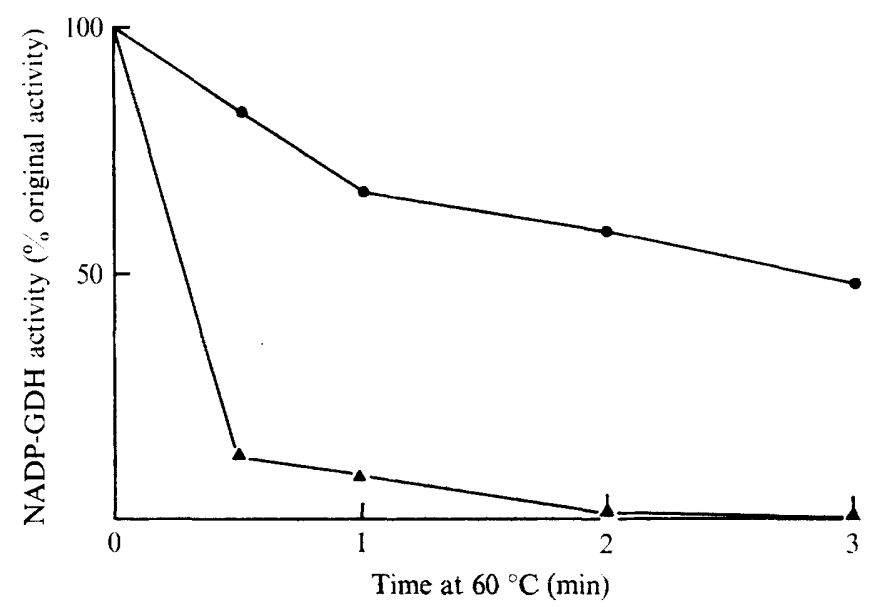

Fig. 2. Temperature decay curves for NADP-GDH in crude extracts of $A$. nidulans. $\bullet$, Wild type; $\boldsymbol{\Delta}, g d h A 20$. For growth of mycelium, see Table I.

Table 4. Ammonium repression of nitrate reductase, xanthine dehydrogenase and thiourea transport in wild-type and gdhA2o strains

\begin{tabular}{|c|c|c|c|c|c|c|}
\hline \multirow[b]{2}{*}{ Strains } & \multicolumn{2}{|c|}{$\begin{array}{c}\text { Xanthine } \\
\text { dehydrogenase* }\end{array}$} & \multicolumn{2}{|c|}{$\begin{array}{l}\text { Nitrate } \\
\text { reductase* }\end{array}$} & \multicolumn{2}{|c|}{$\begin{array}{l}\text { Urea } \\
\text { transport* }\end{array}$} \\
\hline & $37^{\circ} \mathrm{C}$ & $25^{\circ} \mathrm{C}$ & $37^{\circ} \mathrm{C}$ & $25^{\circ} \mathrm{C}$ & $37^{\circ} \mathrm{C}$ & $25^{\circ} \mathrm{C}$ \\
\hline$b i I, g d h A I^{+}$ & $\mathrm{R}$ & $\mathbf{R}$ & $\mathbf{R}$ & $\mathrm{R}$ & $\mathbf{R}$ & $\mathbf{R}$ \\
\hline bir, gdhA2o & D & $\mathbf{R}$ & D & $\mathbf{R}$ & D & $\mathbf{R}$ \\
\hline Remaining $g d h A$ & D & D & D & D & D & D \\
\hline
\end{tabular}

$\mathrm{R}$, system repressed by ammonium; D, system not repressed by ammonium. * Determined by plate tests.

\section{Growth responses of gdhA mutants}

All ( $g d h A I$ to $A 4 I$ ) the mutants except $g d h A 20$ have growth responses similar to that of gdhAI (Kinghorn \& Pateman, I973a). Table 3 shows the growth of $g d h A 20$ compared with $g d h A I$ and wild-type with various nitrogen sources at 25 and $37^{\circ} \mathrm{C}$. The mutant $g d h A 2 O$ is similar to $g d h A r$ in its response to inorganic nitrogen as sole nitrogen source at $37^{\circ} \mathrm{C}$, and has a wild-type response at $25^{\circ} \mathrm{C}$. 


\section{NADP-GDH activity in gdhAzo}

Figure 2 shows the thermal inactivation of NADP-GDH at $60{ }^{\circ} \mathrm{C}$ in crude extracts of gdhA20. There was complete loss of enzyme activity in extracts of $g d h A 20$ held at $60^{\circ} \mathrm{C}$ for up to $3 \mathrm{~min}$. There was some loss of enzyme activity when $g d h A 2 O$ extracts were held at $55^{\circ} \mathrm{C}$, and no loss after treatment at $50{ }^{\circ} \mathrm{C}$ for periods up to $30 \mathrm{~min}$.

\section{Ammonium regulation}

The results presented in Table 4 show that the mutation $g d h A 20$ results in the failure of ammonium to repress nitrate reductase, xanthine dehydrogenase and urea transport at $37^{\circ} \mathrm{C}$ but not at $25^{\circ} \mathrm{C}$. All other $g d h A$ mutants isolated were derepressed for xanthine dehydrogenase, nitrate reductase and urea transport at both temperatures.

\section{DISCUSSION}

It is likely that $g d h A$ is the structural gene for NADP-GDH. There are four main lines of evidence which indicate this. First, a total of $4 \mathrm{I}$ mutants have been isolated which lack normal NADP-GDH activity, and all the mutations map in the $g d h A$ locus. Second, gdhA9 NADP-GDH shows abnormally high Michaelis constants for all five substrates, indicating the production of an abnormal enzyme protein. Third, immunologically active material found in significant amounts in three out of five $g d h A$ mutants examined is presumably the result of missense mutations or nonsense mutations. Finally, $g d h A z O$ produces NADP-GDH that is more sensitive to heat than the wild-type enzyme.

Although it is clear that $g d h A$ is the structural gene for NADP-GDH, the basis of the regulatory effect is not known for certain. It remains an open question whether this is due to a defect of the NADP-GDH protein itself or to a metabolite, the concentration of which is affected by lack of NADP-GDH activity.

The support received from the Science Research Council (grant No. B/RG/48502) is gratefully acknowledged. We thank Miss Isobel C. Chrichton for excellent technical assistance, and Mr J. Heggie for photographic assistance.

\section{REFERENCES}

Adelberg, E. A., Mandel, M. \& Chen, G. C. C. (1965). Optimum conditions for mutagenesis by $N$-methyl$N^{\prime}$-nitro- $N$-nitrosoguanidine in Escherichia coli $\mathrm{K}$ I2. Biochemical and Biophysical Research Communications 18, 788-795.

ARST, H. N. \& MacDonald, D. W. (1973). A mutant of Aspergillus nidulans lacking NADP-linked glutamate dehydrogenase. Molecular and General Genetics 122, 26I-265.

CoHen, B. L. (1972). Ammonium repression of extracellular protease in Aspergillus nidulans. Journal of General Microbiology 71, 293-299.

CoHen, B. L. (1973). Regulation of intracellular and extracellular neutral and alkaline proteases in Aspergillus nidulans. Journal of General Microbiology 79, 3I I-320.

Dunn, E. \& Pateman, J. A. (1972). Urea and thiourea uptake in Aspergillus nidulans. Heredity $29,129$.

Fincham, J. R. S. \& Bond, P. A. (1960). A further genetic variety of glutamic acid dehydrogenase in Neurospora crassa. Biochemical Journal 77, 96-105.

Fincham, J. R. S. \& STAdleR, D. R. (1965). Complementation relationships of Neurospora am mutants in relation to their formation of abnormal varieties of glutamate dehydrogenase. Genetical Research 6 , I 2 I-I 29. 
HyNes, M. J. \& PATEMAN, J. A. (1970a). The genetic analysis of regulation of amidase synthesis in Aspergillus nidulans. I. Mutants unable to utilize acrylamide. Molecular and General Genetics 108, 97-106.

Hynes, M. J. \& Pateman, J. A. (I970 $b$ ). The genetic analysis of regulation of amidase synthesis in Aspergillus nidulans. II. Mutants resistant to fluoroacetamide. Molecular and General Genetics 118, 107-1 16.

Kinghorn, J. R. \& PAteman, J. A. (1972). Regulation of glutamate transport in Aspergillus nidulans. Heredity 29, I 28.

KINGHORN, J. R. \& PATEMAN, J. A. (I973a). NAD and NADP L-glutamate dehydrogenase and ammonium regulation in Aspergillus nidulans. Journal of General Microbiology 78, 39-46.

Kinghorn, J. R. \& Pateman, J. A. (1973 b). A new class of mutants affecting ammonium regulation and methylammonium resistance in Aspergillus nidulans. Heredity 31, 427.

Markert, C. L. \& Moller, F. (1959). Multiple forms of enzymes: tissue ontogenetic and other specific patterns. Proceedings of the National Academy of Sciences of the United States of America 45, 753-759.

Pateman, J. A. \& Cove, D. J. (1967). Regulation of nitrate reduction in Aspergillus nidulans. Nature, London 215, 1234-1239.

Pateman, J. A., Dunn, E., Kinghorn, J. R. \& Forbes, E. (1974). Ammonium and methylammonium transport in wild type and mutant cells of Aspergillus nidulans. Molecular and General Genetics 133, 225-236.

Pateman, J. A. \& Fincham, J. R. S. (1964). Complementation and enzyme studies of revertants induced in an am mutant of Neurospora crassa. Genetical Research 6, 419-432.

Pateman, J. A., Kinghorn, J. R. \& DunN, E. (1974). Regulatory aspects of L-glutamate transport in Aspergillus nidulans. Journal of Bacteriology II9, 534-542.

Pateman, J. A., Kinghorn, J. R., Dunn, E. \& Forbes, E. (1973). Ammonium regulation in Aspergillus nidulans. Journal of Bacteriology 114, 943-950.

Pontecorvo, G., Roper, J. A., Hemmons, L. M., MacDonald, K. D. \& Bufton, A. W. J. (I953). The genetics of Aspergillus nidulans. Advances in Genetics 5, 14I-238.

Poulik, M. D. (1957). Starch gel electrophoresis in a discontinuous system of buffers. Nature, London 180, I477-I479.

Scazzocchio, C. \& Darlington, A. J. (1968). The induction and repression of the enzymes of purine breakdown in Aspergillus nidulans. Biochimica et biophysica acta 166, 557-568.

SMithiEs, O. (1955). Zone electrophoresis in starch gells: group variations in the serum protein of normal human adults. Biochemical Journal 6r, 629-635.

STACHOW, C. S. \& SanwaL, B. D. (1967). Regulation, purification and some properties of the NAD-specific glutamate dehydrogenases of Neurospora. Biochimica et biophysica acta 139, 294-307. 